\title{
PENINGKATAN KEMAMPUAN MENULIS TEKS ANEKDOT DENGAN MENGGUNAKAN MODEL PEMBELAJARAN MAKE A MATCH (MENCARI PASANGAN) PADA SISWA KELAS X SMK DHARMA BAKTI 1 MEDAN
}

\author{
oleh \\ Hijrah Purnama Sari Ariga (hijrahpurnamasariariga@gmail.com) \\ Universitas Almuslim, Prodi Pendidikan Bahasa Indonesia
}

\begin{abstract}
Abstrak-Penelitian ini bertujuan untuk mengetahui peningkatan kemampuan menulis teks anekdot dengan menggunakan model pembelajaran make a match (mencari pasangan )pada siswa kelas X SMK Dharma Bakti 1 Medan T.P 2018/2019. Peneltian yang dilaksanakan ini adalah penelitian tindak kelas (PTK).Sample yang diteliti ada 29 siswa SMK Dharma Bakti 1 Medan.Untuk memperoleh data dalam penulisan ini, penulis melakukan tes, siklus I, siklus II dan observasi dari hasil penelitian yang menggunakan tes. Dari hasil penelitian yang menggunkan tes, siklus I dan siklus II pada pelajaran menulis teks anekdot memperoleh peningkatan ketuntaan hasil belajar yang signifikan.Ketuntaan hasil belajar pada tes awal (prasiklus) $10,34 \%$, pada siklus I menjadi $31.03 \%$, selanjutnya diketahui bahwa pada siklus II tuntas dengan hasil 93,10. Berdasarkan data tersebut dapat diartikan bahwa penggunaan model pembelajaran Make a Match (MencariPasangan) meningkatkan hasil belajar siswa pada pelajaran menulis teks anekdot kelas X SMK Dharma Bakti 1 Medan.
\end{abstract}

Kata Kunci: Kemampuan Menulis Teks Anekdot, Make A Match (Mencari Pasangan)

\section{A. PENDAHULUAN}

Bahasa Indonesia adalah salah satu bidang studi yang diajarkan disetiap sekolah. Bahasa Indonesia merupakan bahasa nasional yang mampu dipergunakan dengan baik dan benar oleh masyarakat indonesia. Bahasa Indonesia salah satu bahasa yang diujikan saat ujian nasional dan merupakan salah satu syarat kelulusan bagi sekolah.Pada kenyataannya bahwa nilai dari ujian nasional adalah nilai terendah dari beberapa mata pelajaran yang diujikan. . Kegiatan menulis yang tidak terbiasa, malas yang menjadi salah satu pemicu rendahnya pengetahuan tentang pelajaran bahasa Indonesia.

Dari permasalahan tersebut dapat dinyatakan bahwa kegiatan menulis sangatlah penting untuk mengembangkan $\begin{array}{lrr}\text { keterampilan dan } & \text { menambah } \\ \text { wawasan.Demikian } & \text { juga } & \text { dengan }\end{array}$ pembelajaran menulis. Menurut Tarigan (2008 : 1) keterampian berbahasa mempunyai empat komponen, yaitu: keterampilan menyimak, keterampian berbicara, keterampilan menulis dan keterampilan membaca. Keempat komponen saling berhubungan satu sama lain. Menulis merupakan suatu keterampilan berbahasa yang dipergunakan untuk berkomunikasi secara tidak langsung, tidak secara tatap muka dengan orang lain. Menulis merupakan kegiatan yang produktif dan ekspresif. Keterampilan menulis tidak akan datang secara otomatis, tetapi harus melalui latihan dan praktik yang banyak dan teratur. 
Dalam keterampilan menulis dituntut untuk menguasai kosa kata, pengetahuan dan pengalaman agar dapat menyampaikan gagasan-gagasan dengan baik kepada pembaca. Kartono (2009 : 17) menyatakan bahwa menulis adalah proses menuangkan pikiran dan menyampaikan kepada khalayak. Namun dalam proses pembelajaran masih banyak siswa kurang termotivasi, sulit menentukan topik, menuangkan gagasannya kedalam bentuk tulisan dan cenderung pembelajaran yang diterapkan guru kurang keatif. Penggunaan metode pembelajaran yang lebih sering diterapkan oleh guru yaitu metode ceramah. Guru menerangkan saja didepan dan kemudian guru hanya sekedar menanyakan apakah mereka sudah mengerti atau tidak.

Hal seperti inilah yang penulis temukan berdasarkan hasil observasi di sekolah SMK Dharma Bakti 1 Medan. Dari hasil yang penulis terima, penulis melihat bahwa kemampuan menulis siswa masih ada yang berada dibawah nilai KKM (Kriteria Ketuntasan Minimum), nilai KKM bahasa Indonesia kelas X SMK Dharma Bakti 1 Medan sebesar 75, dan ada sebanyak $40 \%$ siswa yang nilai kemampuan menulis masih dibawah KKM. Untuk mencegah dan mengantisipasi masalah-masalah yang terjadi sebagai pemicu malas belajar, peneliti ingin memperbaiki kekurangan cara belajar siswa khususnya dengan kegiatan belajar menulis teks anekdot.

Maka salah satu model pembelajaran yang ditawarkan dalam tulisan ini adalah model pembelajaran Make a match (Mencari pasangan) untuk mengantisipasi masalah yang terjadi dalam pembelajaran. Adapun tujuan dari penggunaan model pembelajaran Make a match ( Mencari pasangan) ini adalah siswa lebih aktif untuk mengembangkan kemampuan berfikir dan juga dapat memberikan kesempatan kepada siswa untuk bertanya dan mengeluarkan pendapat serta berinteraksi dengan siswa yang menjadikan aktif dalam kelas.

Dalam model pembelajan Make a match ( mencari pasangn) ini guru akan menyiapkan beberapa pertanyaan yang sesuai dengan materi yang dipelajari (jumlahnya tergantung tujuan pembelajaran) kemudian menulisnya dalam kartu-kartu pertanyaan. Guru membuat kunci jawaban dari pertanyaanpertanyaan yang telah dibuat dan menulisnya dalam kartu-kartu jawaban. Akan lebih baik jika kartu pertanyaan dan kartu jawaban berbeda warna. Kemudian membuat aturan yang berisi pengahargaan bagi siswa yang berhasil dan sanksi bagi siswa yang gagal (guru dapat membuat aturan ini bersama sama dengan siswa). Setelah itu guru menyediakan lembar jawaban untuk mencatat pasanganpasangan yang berhasil sekaligus untuk penskoran presentasi.

Materi yang dibahas dalam tulisan ini adalah tentang teks anekdot.Kemampuan menulis teks anekdot siswa SMK Dharma Bakti 1 Medan masih rendah.Hal ini diakibatkan karena kemungkinan tugas tidak diperiksa sehingga siswa tidak tahu sejauh mana kemampuan mereka dalam menulis teks anekdot. Hal lain juga yang mengakibatkan rendahnya kemampuan siswa dalam menulis teks anekdot karena kosa kata yang sedikit. Minat siswa untuk menulis sangat rendah.Hal ini dapat disebabkan karena fasilitas perpustakaan yang kurang, yaitu buku atau bahan yang dicari siswa tidak ada sehingga siswa malas mengunjungi perpustakaan.

Berdasarkan hal tersebut peneliti tertarik untuk meneliti apakah ada hasil 
atau penigkatan ketika model pembelajaran Make a match (Mencari pasangan) diterapkan saat materi pembelajaran menulis teks anekdot.

Kamus Besar Bahasa Indonesia (KBBI) (2012: 1497) menyatakan bahwa menulis adalah membuat huruf atau angka dengan pena. Menurut Suparno dan Yunus (dalam Dalman, 2014: 4) menyatakan bahwa menulis adalah suatu kegiatan penyampaian pesan (komunikasi) dengan menggunakan bahasa tulis sebagai alat atau medianya. Selanjutnya, Tarigan (dalam Dalma, 2014:4) menyatakan bahwa Menulis merupakan menurunkan atau melukiskan lambang-lambang grafis yang menghasilkan suatu bahasa yang dipahami oleh seseorang sehingga orang lain dapat membaca lambang-lambang grafis tersebut dan dapat memahami bahasa dan grafis itu. Marwoto (dalam Dalma, 2014: 4) menjelaskan bahwa menulis adalah mengungkapkan ide atau gagasannya dalam bentuk karangan secara leluasa. Berdasarkan pengertian beberapa pendapat diatas dapat disimpulkan bahwa menulis adalah kegiatan penyampaian pesan melalui bahasa tulis sebagai media atau alatnya.

Menurut Kamus Besar Bahasa Indonesia (2008:62), Anekdot adalah cerita singkat yang menarik karena lucu dan mengesankan, biasanya mengenai orang penting atau terkenal dan berdasarkan kejadian yang sebenarnya. Menurut Sudaryat (2008:169) Teks anekdot merupakan bagian dari tulisan narasi. Tulisan narasi isinya memaparankan terjadinya suatu peristiwa, baik peristiwa rekaan, maupun kenyataan.Berkenaan dengan peristiwa itu dipaparkan siapa pelakunya, bagaimana pelakunya, dimana tempat peristiwa itu, kapan terjadinya, bagaimana suasana kejadiannya, bagaimana jalan ceritanya, dan siapa juru ceritanya.Tulisan narasi dapat bersifat factual maupun imajinatif seperti dongeng, novel, biografi, sketsa dan anekdot. Pada umumnya, anekdot dianggap sama dengan cerita lucu, padahal kedua teks tersebut berbeda

Anekdot merupakan cerita lucu yang biasanya mengenai orang terkenal yang dapat mengundang tawa. Anekdot yang baik adalah anekdot yang dapat menimbulkan tawa bagi pembaca karena anekdot jalannya ceritanya terkadang membutuhkan penafsiran yang baik untuk memahaminya.

Awalnya teks anekdot hanya mengenai orang terkenal atau kritikan terhadap orang penting tetapi seiring berjalannya waktu anekdot tidak harus berisi cerita orang penting tetapi juga cerita pengalaman pribadi yang menggelikan. Teks anekdot saat ini adalah cerita pengalaman lucu atau konyol dari seseorang.Teks ini bertujuan menghibur pembaca karena berisi pengalaman atau cerita lucu.

Shoimin, (2014:52) model pembelajaran Make a match (Mencari Pasangan) merupakan model pembelajaran yang dikembangkan Loma Curran. Ciri utama Make a match (Mencari Pasangan) adalah siswa diminta mencari pasangan kartu yang merupakan jawaban atau pertanyaan materi tertentu dalam pembelajaran. Salah satu keunggulan teknik ini adalah siswa mencari pasangan sambil belajar mengenai suatu konsep atau topik dalam suasana yang menyenangkan. Teknik ini bisa digunakan dalam semua mata pelajaran dan untuk semua tingkatan usia (Isjoni, 2010: 78).

Istarani (2011:1) menyatakan model pembelajaran adalah seluruh rangkaian penyajian materi ajar ang meliputi segala 
aspek sebelum sedang dan sesudah pembelajaran yang dilakukan guru serta segala fasilitas yang terkait yang digunakan secara langsung dalam proses belajar mengajar.

Berdasarkan beberapa pengertian tersebut dapat disimpulkan bahwa model pembelajaran adalah pedoman bagi pengajar dalam merancang materi pembelajaran, merancang aktifitas belajar mengajar dan fasilitas yang digunakan dalam proses pembelajaran secara terstruktur. Menurut Rusman (2014: 223) langkah-langkah dalam pelaksanaan model Make a match (Mencari Pasangan) yaitu;

1. Guru menyiapkan beberapa kartu yang berisi konsep atau topik pelajaran, sebaliknya satu bagian kartu satu soal dan bagian yang lainnya kartu jawaban.

2. Setiap siswa mendapat satu buah kartu.

3. Setiap siswa memikirkan jawaban atau soal dari kartu yang dipegang.

4. Setiap siswa mencari pasangan yang mempunyai kartu yang cocok dengan kartunya (soal jawaban)

5. Setiap siswa yang dapat menyiapkan kartunya sebelum batas waktu diberi poin.

6. Setelah satu babak kartu dikocok lagi agar tiap siswa mendapat kartu yang berbeda dari sebelumnya.

7. Demikian seterusnya.

8. Kesimpulan atau penutup.

B. METODOLOGI PENELITIAN

Penelitian ini dilaksanakan di SMK Dharma Bakti 1 Medan di jalan Jamin Ginting kelas $\mathrm{X}$ Tahun Pembelajaran 2017/2018.Penelitian ini dilakukan selama tiga bulan dimulai dari bulan Juni 2017 sampai Agustus 2017.
Penelitian ini merupakan penelitian tindakan kelas (PTK).PTK dilaksanakan demi perbaikan atau peningkatan praktik pembelajaran secara berkesinambungan yang pada dasarnya melekat pada terlaksananya misi professional pendidik seorang guru.

Berdasarkan hal tersebuat pendekatan yang digunakan dalam penelitian ini adalah pendekatan kualitatif.Pendekatan kualitatif merupakan jenis penelitian yang didasarkan atas data deskriptif dari setiap individu berupa sikap dan oerilaku yang bisa diamati selama proses pembelajan berlangsung.

Dalam menganalisis data dalam penelitian ini menggunakan teknik analisis deskriptif kualitatif. Analisis deskriptif kualitatif yaitu suatu metode penelitian yang bersifat menggambarkan kenyataan atau fakta sesuai dengan data yang diperoleh dengan tujuan untuk mengetahui hasil belajar yang dicapai siswa untuk mengetahui respon siswa terhadap kegiatan pembelajaran serta aktivitas siswa selama proses pembelajaran berlangsunng. Analisis dihitung dengan menggunakan statistic sederhana, yaitu sebagai berikut:

Peneliti menjumlahkan nilai yang diperoleh siswa kemudian dibagi dengan jumlah siswa kelas tersebut sehingga diperoleh nilai rata-rata. Nilai rata-rata ini didapat dengan menggunakan rumus:

$$
\mathrm{X}=\frac{\sum x}{\sum N}
$$

Keterangan:

$\mathrm{X}=$ nilai rata-rata

$\sum=$ jumlah semua nilai siswa

$\sum \mathrm{N}=$ jumlah siswa

Selanjutnya dapat diketahui dalam ketutntasan belajar siswa dapat tercapai dari persentase siswa yang suadh tuntas dalam belajar. Untuk mengetahui 
persentase ketuntasan belajar siswa, menurut Trianto (2009:24) digunkan rumus:

$$
\mathrm{P}=\frac{\sum \text { siswa yang tuntas belajar }}{\sum \text { siswa }} \times 100 \%
$$

\section{HASIL DAN PEMBAHASAN}

Hasil tes awal (prsiklus) pada kemampuan menulis teks anekdot siswa kelas X SMK Dharma Bakti 1 Medan masih perlu ditingkatkan. Data pada tabel 4.1 menunjukkan bahwa rata rata skor yang diperoleh siswa pada tes awal sebesar 63,79. Dengan tingkat ketuntasan secara klasikal 10,35\%. Dengan demikian, pada kondisi awal kemampuan menulis teks anekdot siswa dapat disimpilkan belum mencaapi hasil yang diharapkan. Siswa yang mendapat nilai 85-100 dalam kategori sangat baik sebanyak 1orang dengan persentase $3,44 \%$, siswa yang memperoleh nilai 75-84 dengn kategori baik sebanyak 2 orang dengan persentase $6,89 \%$. Siswa yang mendapat nilai $60-74$ dengan kategori cukup sebanyak 22 orang dengan presentase $75,86 \%$. Siswa yang mendapat nilai $<59$ sebanyak 4 orang dengan kategori kurang dengan presentase $13,79 \%$.

Berdasarkan tes 1( siklus I) dapat disimpulkan bahwa kemampuan menulis teks anekdot siswa kelas X SMK Dharma Bakti 1 Medan dalam aspek ketepatan judul memperoleh kemampuan rata-rata 9,13, kemampuan rata-rata siswa untuk aspek kelengakapan isi adalah 9,48, kemampaun rata-rata siswa untuk aspek keaktualan topic adalah 8,31, kemampuan rata-rata sisws untuk aspek kemenarikan anekdot adalah 15,1, kemampuan rata-rata siswa dalam aspek keterpaduan wacana adalah 14,49, kemampuan rata-rata siswa dalam aspek struktur kalimat adalah 13,17, kemampuan rata-rata siswa dalam aspek diksi adalah 4,55.
Rata-rata skor yang diperoleh siswa padas siklus 1 sebesar 74,65. Siswa yang mendapat nilai 85-100 dalam kategori sangat baik sebanyak 3 orang dengan persentase $10,35 \%$, siswa yang memperoleh nilai 75-84 dengn kategori baik sebanyak 18 orang dengan persentase $62,06 \%$. Siswa yang mendapat nilai $60-74$ dengan kategori cukup sebanyak 8 orang dengan presentase $27,59 \%$. Siswa yang mendapat nilai $<59$ sebanyak 0 orang dengan kategori kurang dengan presentase 0\%. Dari tabel 4.5 terssebut juga dapat diketahui ketuntasan hasil belajara siswa pada siklus 1 mencapai $72,41 \%$ atau sebanyak 21 siswa, sedangkan siswa yang tidak tuntas $27,59 \%$ atau sebanyak 8 siswa. Dengan demikian dari hasil tersebut dapat 1.1; disimpulkan bahwa kemampuan siswa belum optimal. Oleh karena itu diperlukan pemberian siklus II sebagai perbsiksn untuk siklus selanjutnya.

\section{Diagram Frekuensi Nilai Kemampuan Menulis Teks Anekdot pada Prasiklus dan Siklus I}

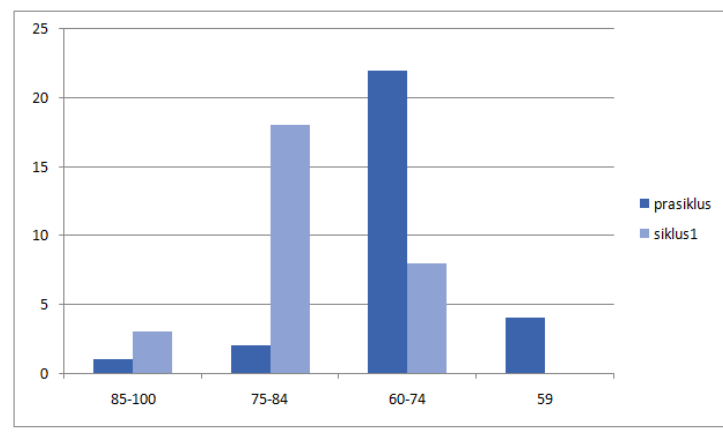

Dari gambar tersebut dapat disimpulkan bahwa kemampuan menilis teks anekdot siswa masih perlu ditingkatkan lahi karena pada siklus I hasilnya masih kurang.Peneliti yakin bahwa nilai ini dapat ditingkatkan lagi.Oleh karena itu, perlu adanya suatu tindakan perbaikan agar siswa mampu mendapat hasil yang maksimal dan lebih lagi dibandingkan sebelumnya. Peneliti akan mengadakan siklus II sebagai 
tindakan perbaikan siklus I dan diharapkan dapat meningkatan nilai siswa dalam menulis teks anekdot.

Berdasarkan tes II( siklus II) dapat disimpulkan bahwa kemampuan menulis teks anekdot siswa kelas X SMK Dharma Bakti 1 Medan dalam aspek ketepatan judul memperoleh kemampuan rata-rata 9,68, kemampuan rata-rata siswa untuk aspek kelengakapan isi adalah 9,86, kemampaun rata-rata siswa untuk aspek keaktualan topic adalah 8,79, kemampuan rata-rata sisws untuk aspek kemenarikan anekdot adalah 16,79, kemampuan ratarata siswa dalam aspek keterpaduan wacana adalah 15,68 , kemampuan ratarata siswa dalam aspek struktur kalimat adalah 14,24 kemampuan rata-rata siswa dalam aspek diksi adalah 5 .

Berdasarkan pemaparan diatas, dapat dijelaskan bahwa perolehan skor rata-rata kemampuan menulis teks anekdot siswa kelas X SMK Dharma Bakti 1 Medan adalah 81,03 .

Rata-rata skor yang diperoleh siswa padas siklus II sebesar 81,03 Siswa yang mendapat nilai 85-100 dalam kategori sangat baik sebanyak 6 orang dengan persentase $20,70 \%$, siswa yang memperoleh nilai 75-84 dengn kategori baik sebanyak 21 orang dengan persentase $72,41 \%$. Siswa yang mendapat nilai $60-74$ dengan kategori cukup sebanyak 2 orang dengan presentase $6,89 \%$. Siswa yang mendapat nilai $<59$ sebanyak 0 orang dengan kategori kurang dengan presentase $0 \%$.Ketuntasan hasil tes kemampuan siswa pada siklus II mengalami peningkatan dari siklus I. pada siklus I hanya 21 siswa $(72,41 \%)$ yang tuntas secara klasikal, sedangkan pada siklus II sudah mencaapi hasil yang optimal sesuai dengan indicator ketercapaian, yaitu sebanyak 27 siswa
$(93,10 \%)$ dan yang tidak tuntas 2 siswa $(6,89 \%)$.

\section{Diagram 4.2}

Distribusi frekuensi Nilai Kemampuan menulis Teks Anekdot pada siklus I dan siklus II

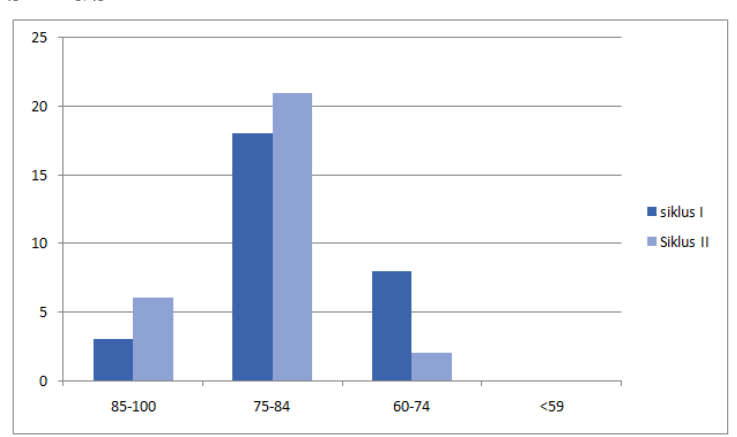

Dari gambar diatas dapat disimpulkan bawha penelitian ini tidak perlu dilanjutkan ke siklus III, karena ketuntasan hasil kemampuan menulis teks anekdot siswa yang memperoleh nilai $\geq 75$ sudah merncapai $80 \%$ sesuai trget capaian sehingga tindakan dapat dihentikan.

Berikut ini dapat dilihat nilai rata rata hasil belajar siswa mulai dari kondisi awal (prasiklus), siklus I dan siklus II.

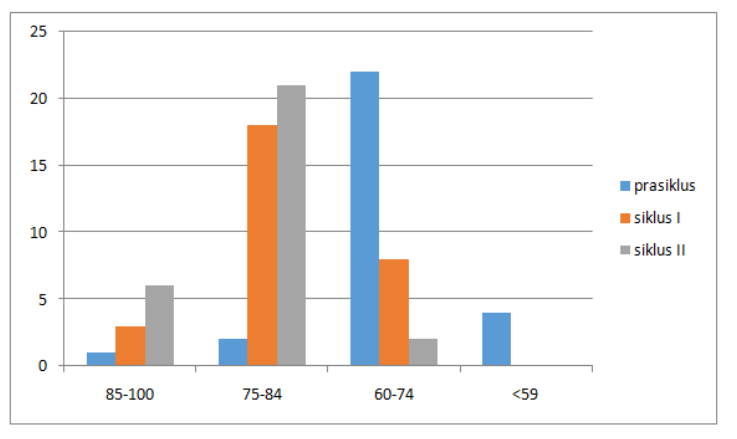

Berdasarkan diagram diatas dapat diambil kesimpulan bahwa danya peningkatan dalam perbandingan antara skor rata-rata siswa pada prasiklus, siklus I dan siklus II. Dari hasil penskoran yang di nilai dalam menulis teks anekdot dapat diketahui perbandingan skor rata rata sebanyak 29 siswa pada prasiklus, siklus I dan siklus II adalag sebagai berikut: 


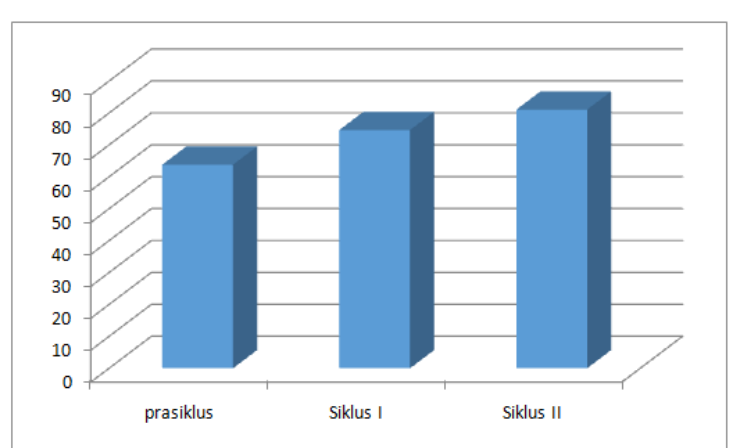

Diagram Perbandingan Persentase Siklus Siswa Tuntas Pada Prasiklus, Siklus I Dan Siklus II

Berdasrakan diagram diatas dapat disimpulkan bahwa jumlah skor rata rata kelas sebanyak 29 siswa pada prasiklus sebesar 63,79, jika dipersentasekan sebesar 10,35\%, siklus I sebesar 74,65, jiks dipersentasekan sebesar 72,41\%, siklus II sebesar 81,03, jika dipersentasekan sebesar 93,10\%. Dapat diambil kesimpulan bahwa skor rata-rata kemampuan menulis teks anekdot siswa kelas X SMK Dharma Bakti 1 Medan megalami peningkatan.

\section{Kesimpulan dan Saran}

\section{Kesimpualan}

Berdasarakan hasil penelitian tentang kemampuan menulis teks anekdot pada siswa kelas X SMK Dharma Bakti 1 Medan, maka apat disimpulkan bahwa:

a. Kualitas hasil menulis teks anekdot siswa sebelum menggunakan model pembelajaran make a match (mencari pasangan) masih sangat rendah. Hal ini terlihat dari nilai rata rata, 63,79 yang masih jauh dari nilai $K K M$ yaitu $\geq 75$ dengan tingkat ketuntasan klasikal 10,34\%.

b. Kualitas hasil menulis teks anekdot siswa setelah menggunakan model pembelajaran Make a Match (mencari pasangan) pada siklus I mengalami peningkatan dari prasiklus dengan nilai rata-rata 74,65 , dengan tingkat ketuntasan belajar siswa secara klasikal $72,41 \%$, tergolong sedang atau cukup. Pada siklus II terjadi peningkatan dengan nilai rata rata 81,03 dengan tingkat ketuntasan belajar secara klasikal 93,10\% dan tergolong dalam kategori tinggi.

c. Hasil peningkatan kemampuan menulis teks anekdot dengan model pembelajarn make a match (mencari pasangan) terdapat peningkatan kontribusi nilai 20,96\% dari siklus I ke siklus II

\section{Saran}

Berdasarkan simpulan dan hsil penelitian, maka saran yang dapat dikemukakan adalah sebagai berikut:

1. Kepada guru mata oelajaran bahasa Indonesia di kelas X SMK Dharma Bakti 1 Medan disarankan memberikan memberikan pujian kepada siswa ketika menyelesaikan tugas, sehingga siswa lebih semangt dan fokus dalam mengikuti materi pelajaran yang diajarkan.

2. Guru harus dapat mengolah pembelajaran dengan melibatkan seluruh siswa. Sebagai bahan pertimbangan bagi guru untuk menggunakan model pembelajaran make a match (mencari pasangan) dalam mengajar yang dapat meningkatkan hasil belajar peserta didik khususnya pada materi menulis teks anekdot.

3. Kepada siswa di kelas X SMK Dharma Bakti 1 Medan disarankan supaya lebih bergiat belajar dan lebih aktif saat proses belajar mengajar berlangsung.

4. Kepada peneliti berikutnya apabila ingin menggunakan model pembelajaran Make a Match (mencari pasangan) dapat 
menggunakan penelitian ini sebagai bahan referensi saat penelitian berikutnya khususnya pada materi pelajaran bahasa Indonesia.

\section{Daftar Pustaka}

Arikunto, S. 2014. Prosedur Penelitian, Jakarta : Rineka Cipta.

Akhadiah, S., dkk 1989.Pembinaan Kemampuan Menulis Bahasa Indonesia. Jakarta: Erlangga.

Dalman, H. 2011. Keterampilan Menulis, Bandar Lampung: PT Raja Grafindo Persada.

Dalman. 2014. Keterampilan Menulis. Jakarta: Rajawali Pers.

Feronika Hutahean "pengaruh miodel pembelajaran berbasis masalah terhadap kemampuan menulis teks anekdot pada siswa kelas X Sma Negeri 1 Air Putih tahun pembelajaran 2013/2014.

Handiyani, S., dkk, 2014.Bahasa Indonesia 1.Bandung: Grafindo Media Pratama.

Huda, M. 2013. Model-Model Pengajaran dan pembelajaran. Malang: Pustaka Pelajar.

Huda, M. 2013. Model-model Pengajaran dan Pembelajaran: Isu-Isu Metodish dan Paradigma .Yogjakarta : Pustaka Pelajar.

Istarani. 2011. Model Pembelajaran Inovatif. Medan: Iscom.

KBBI.2008 (Edisi Empat).Jakarta : PT Gamedia Pustaka Utama.
Kokasih, E. 2013.Cerdas Berbahasa Indonesia. Jakarta: Erlangga.

Meliana Sirait "pengaruh model pembelajaran karikatur terhadap kemampuan menulis teks anekdot oleh siswa kelas X Sma Negeri 5 Medan Tahun pembelajaran 2014/2015" Universitas Negeri Medan (tidak dipublikasikan).

Moleong, J. 2011. Metodologi Penelitian Kualitatif , Bandung: PT Remaja Rus Dakarya.

Muslich, M. 2009. Melaksanakan PTK Penelitian Tindakan Kelas itu Mudah. Malang: Bumi Aksara.

Rusman, 2014.Model-Model Pembelajaran, Jakarta: PT Raja Grafindo Persada.

Shoimin, A. 2014.68 Model Pembelajaran Inovatif dalam Kurikulum 2013.Rembang: Ar-Ruzz Media.

Sudaryat. Kumpulan Teks Aneksot. [online]. Tersdia: http: /jpbsi. Html. Doc. (28 November 2018).

Sugiyono. 2013. Metode Penelitian Pendidikan. Bandung: Alfabeta.

Suprijono, A. 2011.Coopeative Leraning. Yogjakarta: Pustaka Pemdar.

Semi. 2007. Dasar-dasar Keterampilan Menulis. Jakarta: Angkasa Yustinah.

Tarigan, H. G. 2008. Menulis Sebagai Suatu Kemampuan Berbahasa. Bandung: Angkasa. 